\title{
LAS CERÁMICAS PINTADAS DE LA EDAD DEL COBRE EN VALENCINA DE LA CONCEPCIÓN (SEVILLA)
}

\author{
The painted ceramics in the Calcolithic in \\ Valencina de la Concepción (Sevilla)
}

\author{
Teresa Murillo Díaz y Fernando Fernández Gómez*
}

Recibido el 17 de julio de 2008. Aceptado el 30 de agosto de 2008.

\begin{abstract}
Resumen. Se presenta un conjunto de cerámicas pintadas de la Edad del Cobre halladas durante las excavaciones de urgencia realizadas en Valencina de la Concepción entre los años 1975 y 1989, procediéndose a su estudio comparativo con las halladas en otros yacimientos de la misma época.

Palabras clave: Cerámicas pintadas. Calcolítico. Valencina de la Concepción. Zanjas, silos, pozos, cabañas, drenaje, simbolismo.
\end{abstract}

\begin{abstract}
We present and study here with their contexts a group of selected painted ceramics found in the Calcolitic setlement of Valencina de la Concepción (Seville) during the archaeological excavations made along the years 1975 and 1989.

Key Words: Painted ceramics. Valencina de la Concepción (Seville). Calcolithic, ditches, wells, silos, cottages, drainage, symbolism.
\end{abstract}

\section{EL YACIMIENTO}

La selección de un territorio claramente definido y de espacios abiertos, fértiles, en un punto estratégico, cerca de pasos naturales, fácilmente defendible, repleto de estructuras habitacionales, zanjas, silos, pozos, cabañas, y con un registro arqueológico cargado de contenido informativo, tiene su máxima expresión en el Bajo Valle del Guadalquivir en Valencina de la Concepción.

El yacimiento al que nos referimos, con una extensa área de concentración poblacional, en gran parte rodeada por una banda de monumentos funerarios de la Edad del Cobre, se halla situado sobre las estribaciones del Aljarafe sevillano, afectando a los términos municipales de Valencina de la Concepción, Castilleja de Guzmán, Castilleja de la Cuesta, Gines y Salteras.

El medio físico, desde el punto de vista del relieve, cuyas caracteristicas se han presentado en diversas ocasiones ( $\mathrm{Mu}$ rillo Díaz, 2006: 15-17, 25-30), ofrece cuatro unidades bien diferenciadas que, de Norte a Sur, serian: la Campiña alo- mada de la cuenca del Arroyo Pie de Palo, la Vega del Guadalquivir, el escarpe del Aljarafe y la plataforma elevada sobre la que se extiende lo que ha sido área de ocupación habitacional desde la Prehistoria hasta la actualidad.

Este marco geomorfológico comporta unas connotaciones paisajísticas debidas a determinados aspectos significativos y puntuales que tienen su reflejo en un régimen socioeconómico de captación y de división del trabajo, en el que juega un papel fundamental la explotación de los recursos naturales, por lo que se irá generando una sustitución de ecosistemas naturales por ecosistemas antrópicos. Esta capacidad de uso territorial del paisaje natural en un largo espacio de tiempo lo deja transformado gradualmente en un paisaje cultural.

El yacimiento en su conjunto ocupa una superficie aproximada de 360 Hectáreas, según ha podido constatarse por medio de las frecuentes excavaciones arqueológicas llevadas a cabo durante los últimos años (Murillo Díaz, 2006: 17), las cuales han permitido delimitar con claridad dos zonas principales de ocupación: la habitacional o productiva y la funeraria o de

(*) T. Murillo Diaz: UNED Sevilla. Avda. San Juan de la Cruz n.0 40.41006 Sevilla.tmurillo@sevilla.uned.es

F. Fernández Gómez: Museo Arqueológico de Sevilla. Pza. de América, s/n. 41013 Sevilla. fernando.fernandez.gomez@juantadeandalucia.es 


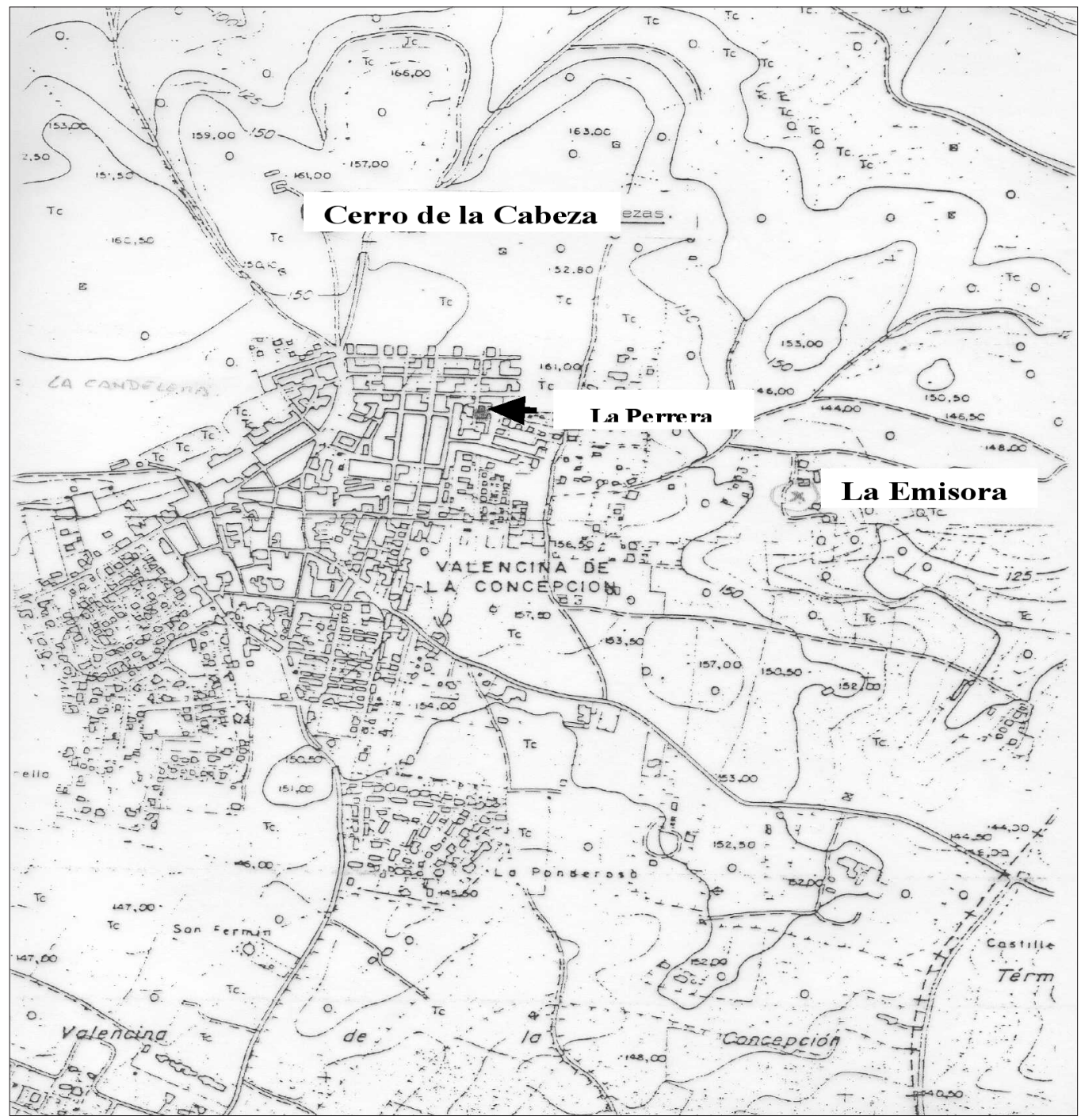

- Figura 1. Plano de excavaciones con hallazgos de cerámica pintada.

necrópolis, aunque este paisaje se nos presenta en ocasiones con alguna imprecisión, puesto que se yuxtaponen elementos de estructuras de habitación con las de enterramiento.

Las áreas de máxima concentración se extienden desde los límites más septentrionales de la Cornisa, Cerro de la Cabeza (Fernández Gómez y Oliva Alonso, 1980), hasta los más meridionales, El Roquetito (Murillo Díaz, 1990: 354-359), con estructuras funerarias. Sin embargo la mayor densidad de construcciones de enterramiento la hallamos en el sector oriental del municipio de Valencina, hacia el término de la localidad limítrofe de Castilleja de Guzmán, con exponentes tan significativos de carácter megalítico como los de La Pastora, Matarrubilla, Ontiveros y Montelirio, dibujando un perímetro funerario en torno al área habitacional.

Las zonas preferentes de ocupación de este poblado de la Edad del Cobre están situadas sobre una plataforma con una cota media de 150 metros sobre el nivel del mar. Concretamente ocupa el sector noreste y centro del casco urbano actual de Valencina. Quedan constatadas la densidad y diversificación de las estructuras habitacionales en zonas como La Perrera (Fernández y Oliva, 1985), el Cerro de la Cabeza (Murillo, Fernández y Oliva, 2006) o La Emisora (Murillo, 1991b), que nos aportan gran información sobre el registro arqueológico material, del que aquí solo queremos destacar por su interés a las cerámicas pintadas.

\section{EXCAVACIONES Y HALLAZGOS}

En la zona amesetada de esta cornisa del Aljarafe, en donde el factor topográfico, como decíamos, marca una distinción sectorial, se presenta un área nuclear de ocupación habitacional productiva, en el sector noreste de la actual localidad, cuyas características han quedado de manifiesto en las excavaciones de La Perrera, El Cerro de la Cabeza, El Polideportivo (Murillo, 1987) y La Emisora, por la calidad y cantidad de la información arqueológica que nos han proporcionado (fig. 1). 
Las primeras iniciativas de búsqueda, localización y documentación del poblado no se producen hasta los años setenta del pasado siglo $\mathrm{XX}$, aunque el yacimiento ya se conocía desde el XIX, cuando se inician las investigaciones, con el objetivo de estudiar los monumentos de arquitectura funeraria (Murillo, 2006: 58 y ss).

En 1975 se realizan excavaciones de urgencia, dirigidas por F. Fernández, en las zonas Ilamadas "La Candelera" y "La Perrera", donde se llevaron a cabo una serie de cortes estratigráficos, $A, B, C$ y $D$, en los que aparecieron las primeras zanjas excavadas en el terreno que han podido ser identificadas en el yacimiento. Se hallaban rodeadas por estructuras siliformes y un posible horno. En el Corte $\mathrm{C}$ el registro arqueológico estaba formado por los ya conocidos platos y fuentes de borde almendrado o engrosado, vasijas lenticulares y hemisféricas, cuencos, cazuelas y otros que se dan a conocer en la memoria (Fernández y Oliva, 1985). Entre los numerosos fragmentos de cerámica cuyos vasos no pudieron reconstruirse, ni siquiera gráficamente, se hallaba uno de pequeño tamaño cuya superficie se encontraba decorada con pintura ( $n^{\circ} .13$ del inventario).

En 1976 se efectuaron nuevas excavaciones de urgencia, dirigidas por F. Fernández y D. Oliva, en la zona denominada Cerro de la Cabeza, el cual estaba siendo desmontado con el fin de extraer áridos para la construcción de la carretera Sevilla-Mérida, y en el que aparecieron nuevas estructuras excavadas en el terreno con un rico registro arqueológico extendido en más de una hectárea, que aportó abundante información sobre el yacimiento.

Se constató allí la existencia de dos zanjas, casi paralelas, que se interpretaron como de drenaje de los terrenos cir- cundantes, pues a ambos lados de ellas aparecían numerosos silos de planta circular, y una posible cabaña de planta rectangular (Murillo, Fernández y Oliva, 2006: 177-196), estructuras todas ellas en las que se halló abundante material arqueológico, del cual hemos querido traer aquí el pequeño conjunto de cerámicas pintadas, una docena larga de fragmentos de entre los miles recogidos, en su totalidad pertenecientes a paredes de vasos de boca cerrada, posibles urnas de formas lenticulares, ovoides o carenadas, pero cuyo perfil en ningún caso ha podido determinarse por el pequeño tamaño de los fragmentos. Su contexto estaba constituido por los conocidos platos y fuentes de cerámica, hojas y puntas de flecha de sílex, y abundante material óseo, agujas, punzones, paletas $y$, destacando sobre el conjunto, dos ídolos antropomorfos (Fernández y Oliva, 1980: 20-44). En el poblado habían sido asimismo numerosos los animales domésticos, ovicápridos, bóvidos, cérvidos, suídos y cánidos (Hain, 1982).

En ese mismo Cerro de la Cabeza había sido localizado el año anterior, 1975, un enterramiento de cámara circular y falsa cúpula, en su mayor parte destruido por las máquinas excavadoras, pero que aún permitió la recogida de algunos elementos del ajuar funerario, en el que había que destacar la presencia de dos platos de borde engrosado cuyo interior aparecía decorado con un motivo reticulado, aunque no pintado sino simplemente bruñido, técnica y motivos que asociaban los excavadores con influencias orientales, del horizonte del Neolítico Final y de la misma Edad del Cobre. Estudiaban asimismo el proceso de manufacturación de estos grandes platos cerámicos, llegando a la conclusión de que debieron hacerse probablemente a "molde" (Fernández y Oliva, 1986: 29) (fig. 2).

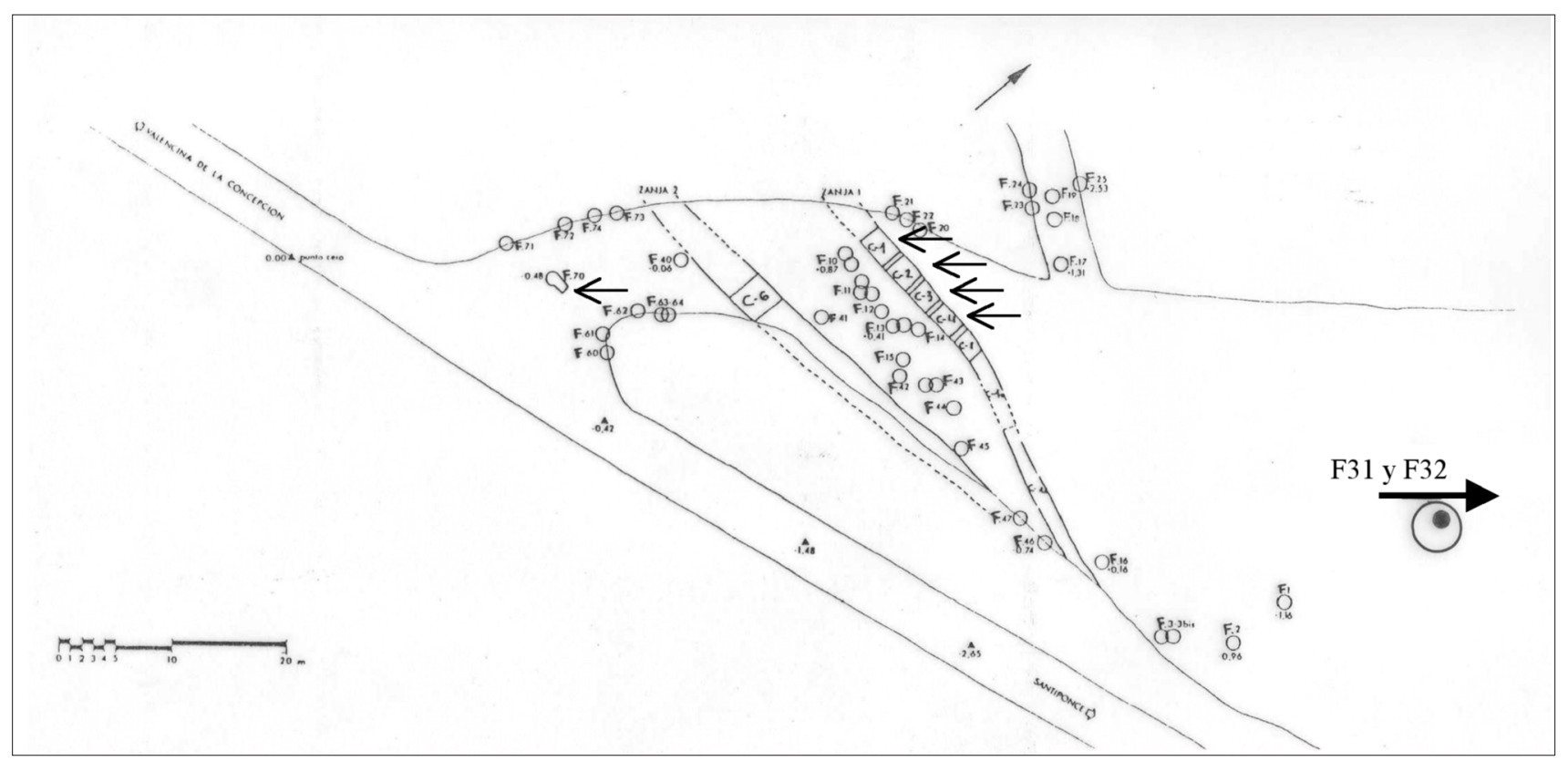

- Figura 2. Excavación en el Cerro de la Cabeza. Situación de los hallazgos de cerámica pintada. Pozos F 31 y F 32; Zanja 1, Cuadrículas C-1, C-2, C-3 y C-11; Zanja 2 y Cabaña F-70. 
A finales de los años ochenta realizamos una nueva excavación de urgencia, en la zona denominada La Candelera, concretamente definimos como La Emisora al solar en donde intervinimos, por estar ubicado en el lugar del actual repetidor de Televisión. (Murillo, 1991 a: 555-558; 1991 b: 19-37 y 2006: 94-96).

La superficie a investigar era de 2,5 Has en las que se excavaron unos 272 metros cuadrados. Se trataba de un área de ocupación habitacional preferente, con gran concentración de estructuras, casi medio centenar, a las cuales podemos clasificar por su aspecto morfológico en silos, pozo, cabaña, talleres, zanja, y horno. Todas las cuales pudimos contextualizar diacrónica y sincrónicamente con las informaciones que teníamos por las excavaciones de Fernández y Oliva de 1985.

Todas y cada una de las estructuras estaban colmatadas de material arqueológico perteneciente a la Plena Edad del Cobre, y de entre todos los artefactos, destacaríamos una espectacular vasija carenada de $240 \mathrm{~mm}$. de diámetro en la boca, decorada con pintura dibujando motivos geométricos, que ha podido ser reconstruida por completo. La hallamos en los niveles superiores de excavación, sobre un pavimento de tierra apisonada, huesos, fragmentos de cerámica y gravilla, que a su vez sellaban dos estructuras siliformes (fig. 3a, b).

Y como característica general de este conjunto de cerámicas decoradas de Valencina, tendríamos que decir que procede siempre de contextos habitacionales y no funerarios, al contrario de lo que parece suceder en la mayoría de los ya- cimientos del Sureste peninsular, cuyo contexto es eminentemente funerario, vinculado a enterramientos de corredor.

\section{RELACIÓN DE HALLAZGOS}

Todos los fragmentos y vasos completos de cerámica pintada que presentamos, pertenecen a excavaciones de urgencias llevadas a cabo en Valencina de la Concepción que hasta el momento estaban inéditos. Pretendemos con este trabajo, partiendo de unos datos primarios, basados en los análisis estratigráficos, llegar a un conocimiento más general de estas cerámicas, para intentar clarificar su presencia en yacimientos de la Edad del Cobre de Andalucía Occidental.

Afrontamos este estudio desde un método fundamentalmente arqueológico, al ser artefactos estratificados en un conjunto de excavaciones de urgencia llevadas a cabo por nosotros mismos, por lo que forman parte de los correspondientes Informes y Memorias de esos trabajos de campo. Para mejor encuadrarlos apuntaremos de pasada algunos aspectos históricos, económicos y sociales en nuestras conclusiones generales.

A estos fragmentos que presentamos ahora habría que añadir los dos que dice poseer Ruiz Mata, procedentes también de las excavaciones del Cerro de la Cabeza (1983: 187), aunque posiblemente se trate de algunos de los que aquí hemos recogido, pues, aunque no los presenta gráficamente, dice que están pintados de rojo o negro sobre fondo más claro, lo mismo que los nuestros.

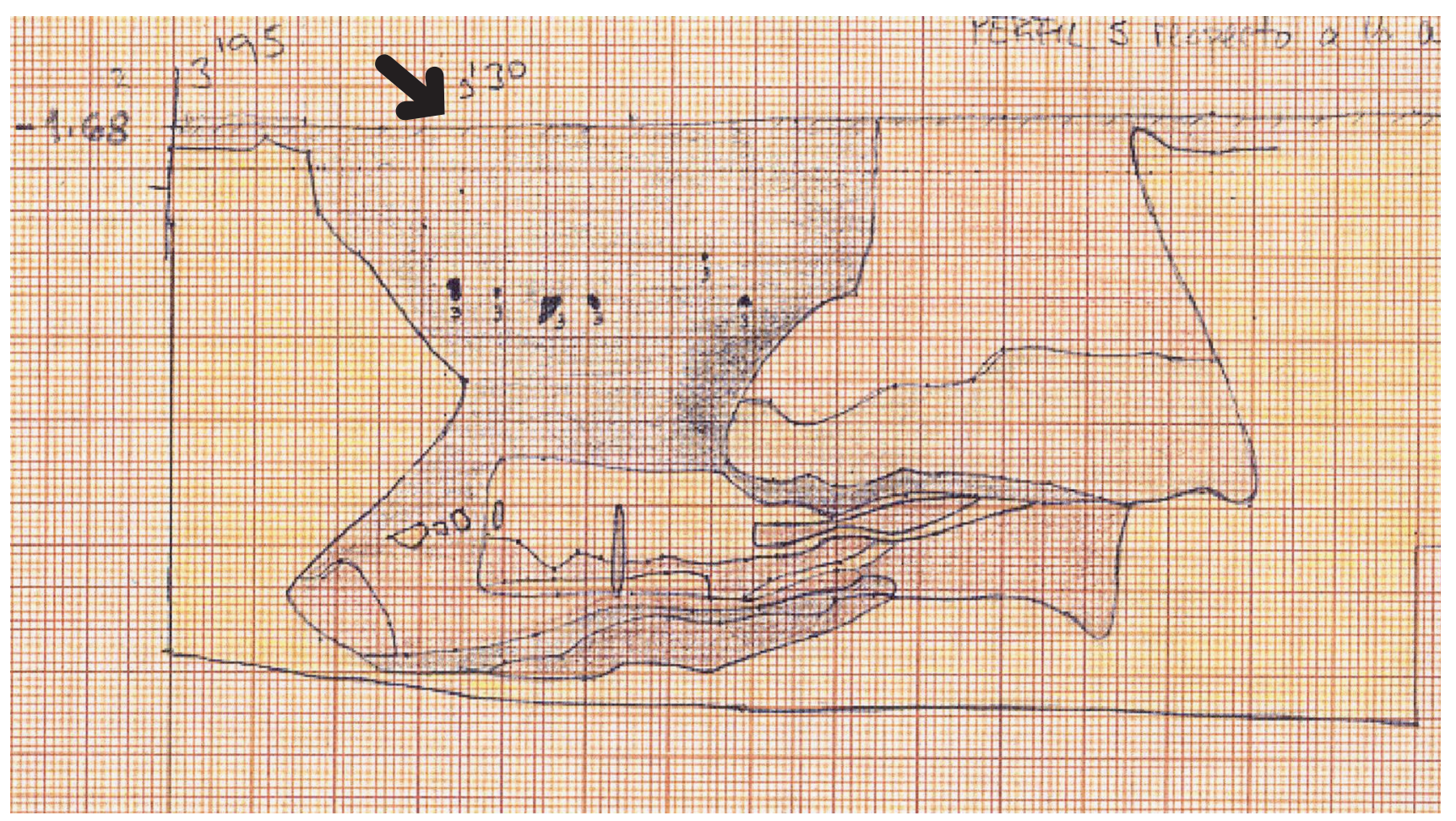

- FIIgura 3. Situación de la vasija pintada sobre las estructuras siliformes de la Cuadricula III de La Emisora. Ubicación de la Vasija Pintada $\mathrm{n}^{\circ} 14$. 

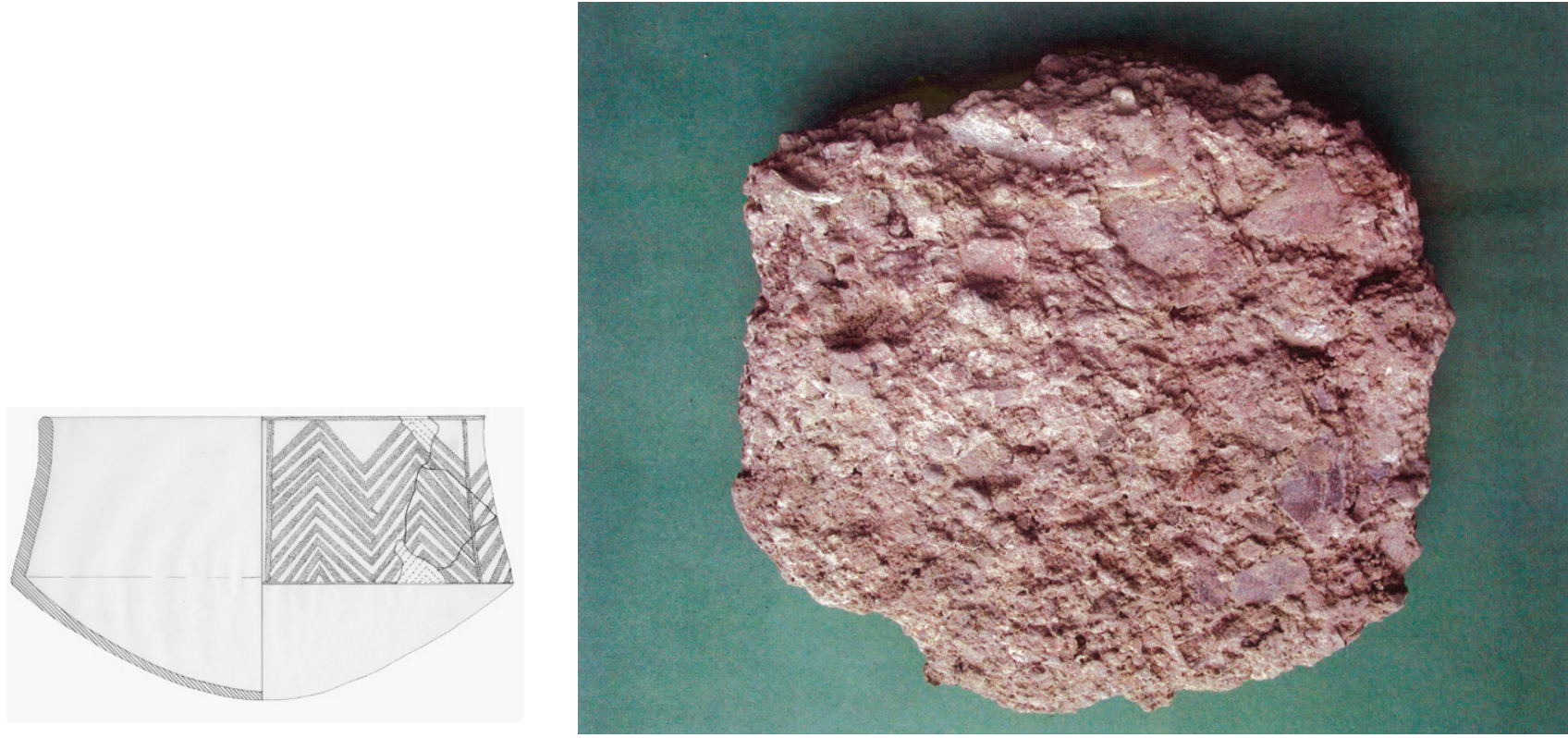

A FIigura 3b. Vasija Pintada $n^{0} 14$. Pavimento sobre el que se hallaba la vasija.

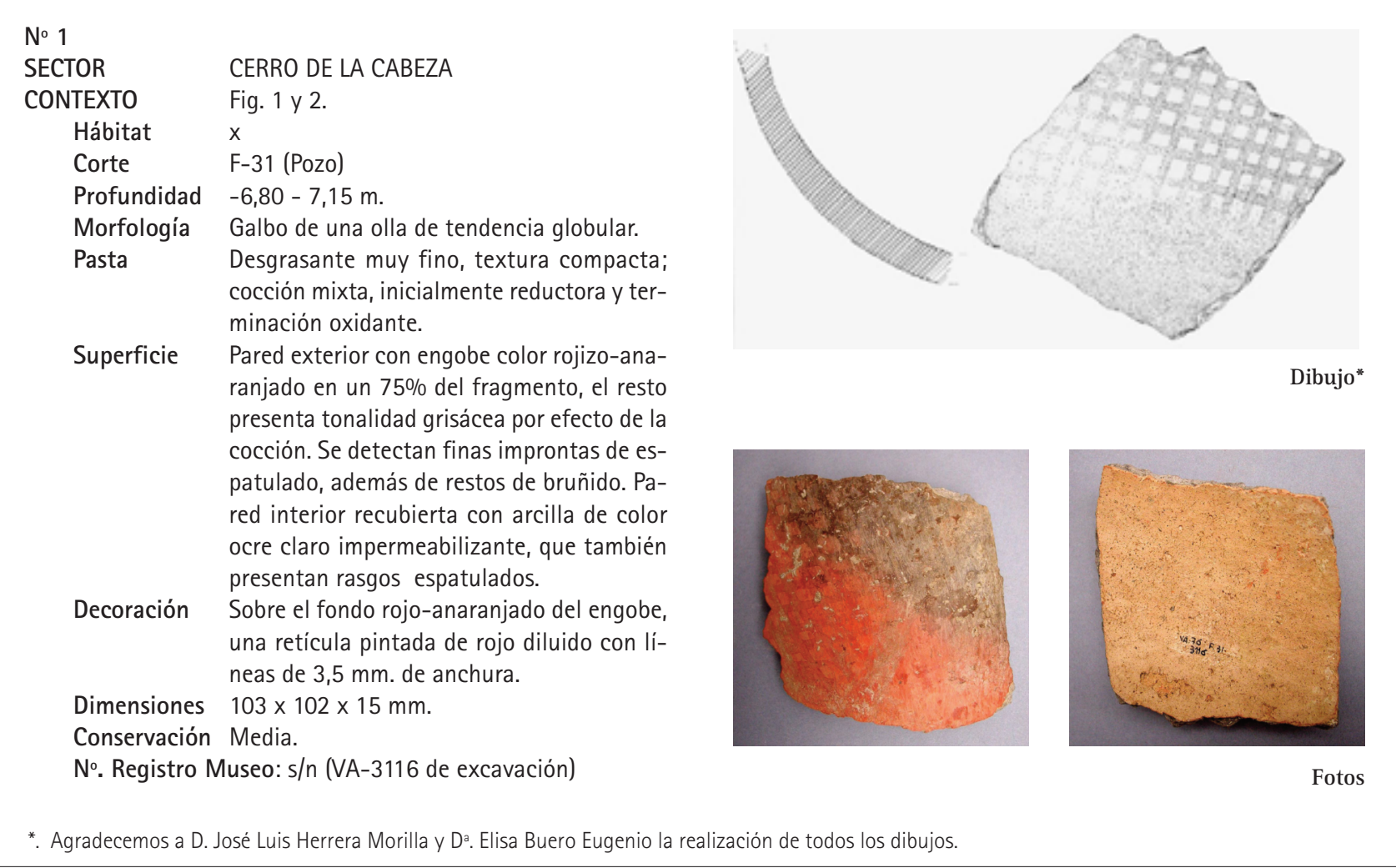




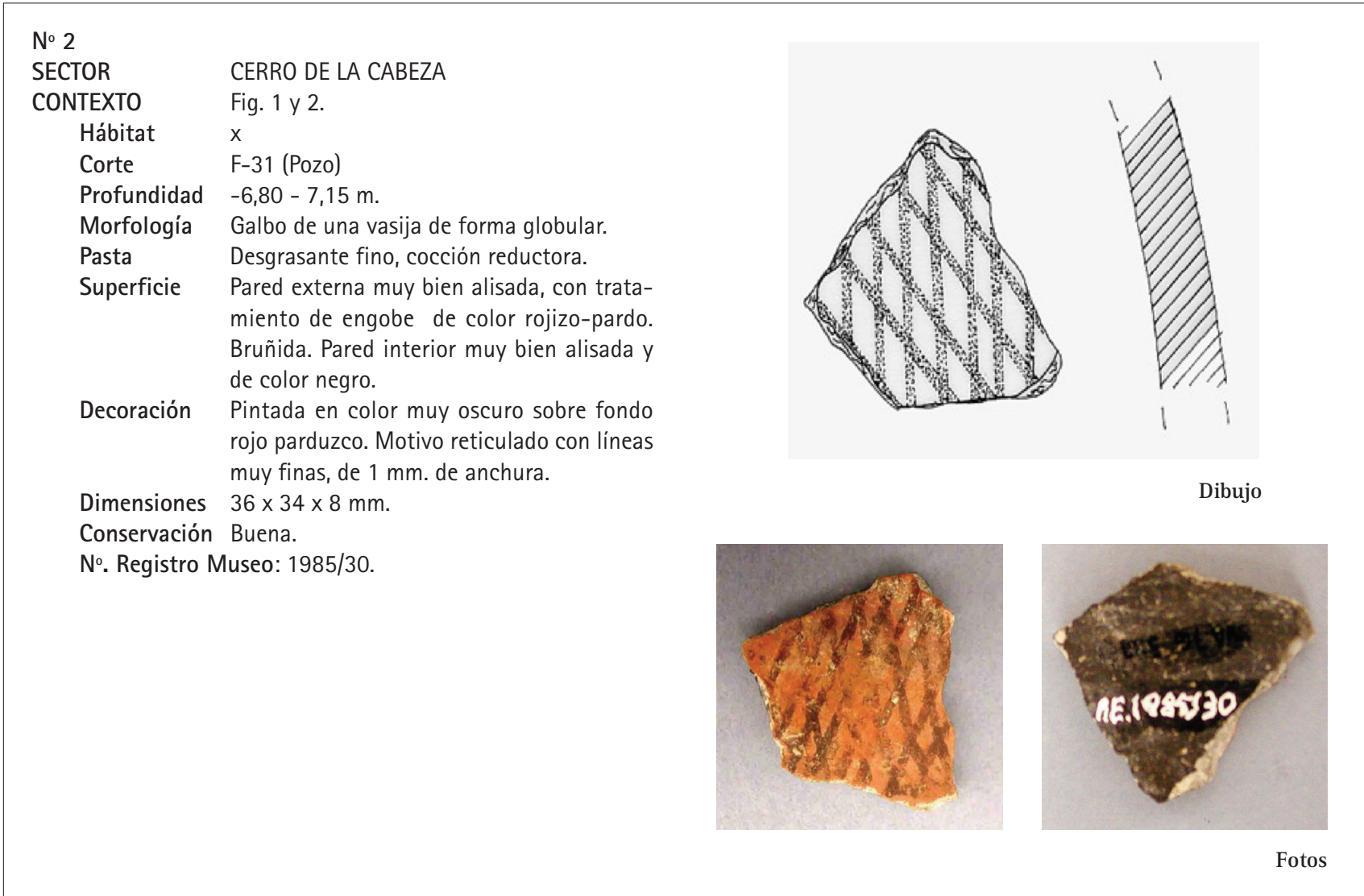

\begin{tabular}{|c|c|}
\hline \multicolumn{2}{|l|}{ № 3} \\
\hline SECTOR & CERRO DE LA CABEZA \\
\hline CONTEXTO & Fig. 1 у 2. \\
\hline Hábitat & $\mathrm{x}$ \\
\hline Corte & F-31 (Pozo) \\
\hline Profundidad & Cribado de tierras. \\
\hline Morfología & $\begin{array}{l}\text { Borde de una olla de tendencia globu- } \\
\text { lar. Labio redondeado y ligeramente ex- } \\
\text { vasado. }\end{array}$ \\
\hline Pasta & $\begin{array}{l}\text { Desgrasante muy fino, textura compac- } \\
\text { tada y cocción reductora. }\end{array}$ \\
\hline Superficie & $\begin{array}{l}\text { Pared exterior con engobe de color ro- } \\
\text { jo oscuro, bruñido. Pared interior de co- } \\
\text { lor negruzco, alisada. }\end{array}$ \\
\hline Decoración & $\begin{array}{l}\text { Pintada en color muy oscuro sobre fon- } \\
\text { do rojo; una línea horizontal enmar- } \\
\text { cando el borde, de la que parten bandas } \\
\text { oblicuas ( } 4 \mathrm{~mm} \text {. anch.) formando che- } \\
\text { vrons con el vértice hacia abajo. }\end{array}$ \\
\hline Dimensiones & $136 \times 51 \times 7 \mathrm{~mm}$ \\
\hline & Media. \\
\hline
\end{tabular}
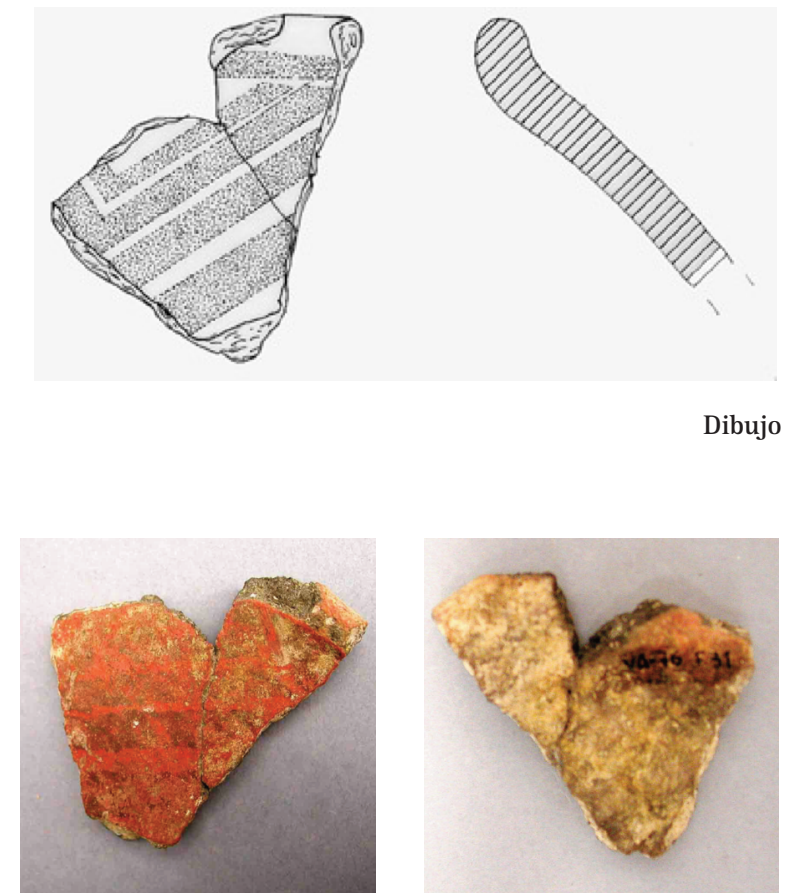


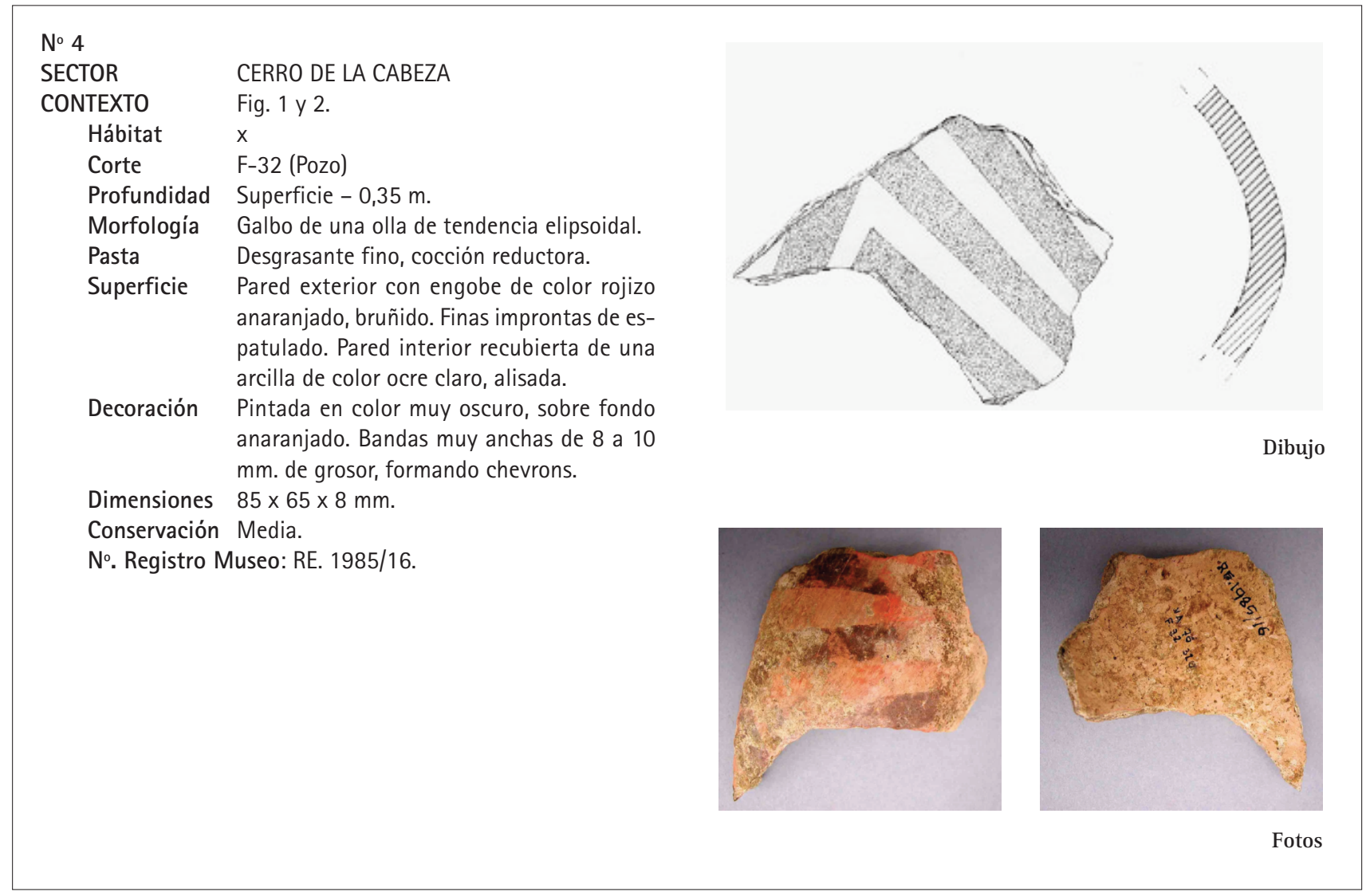

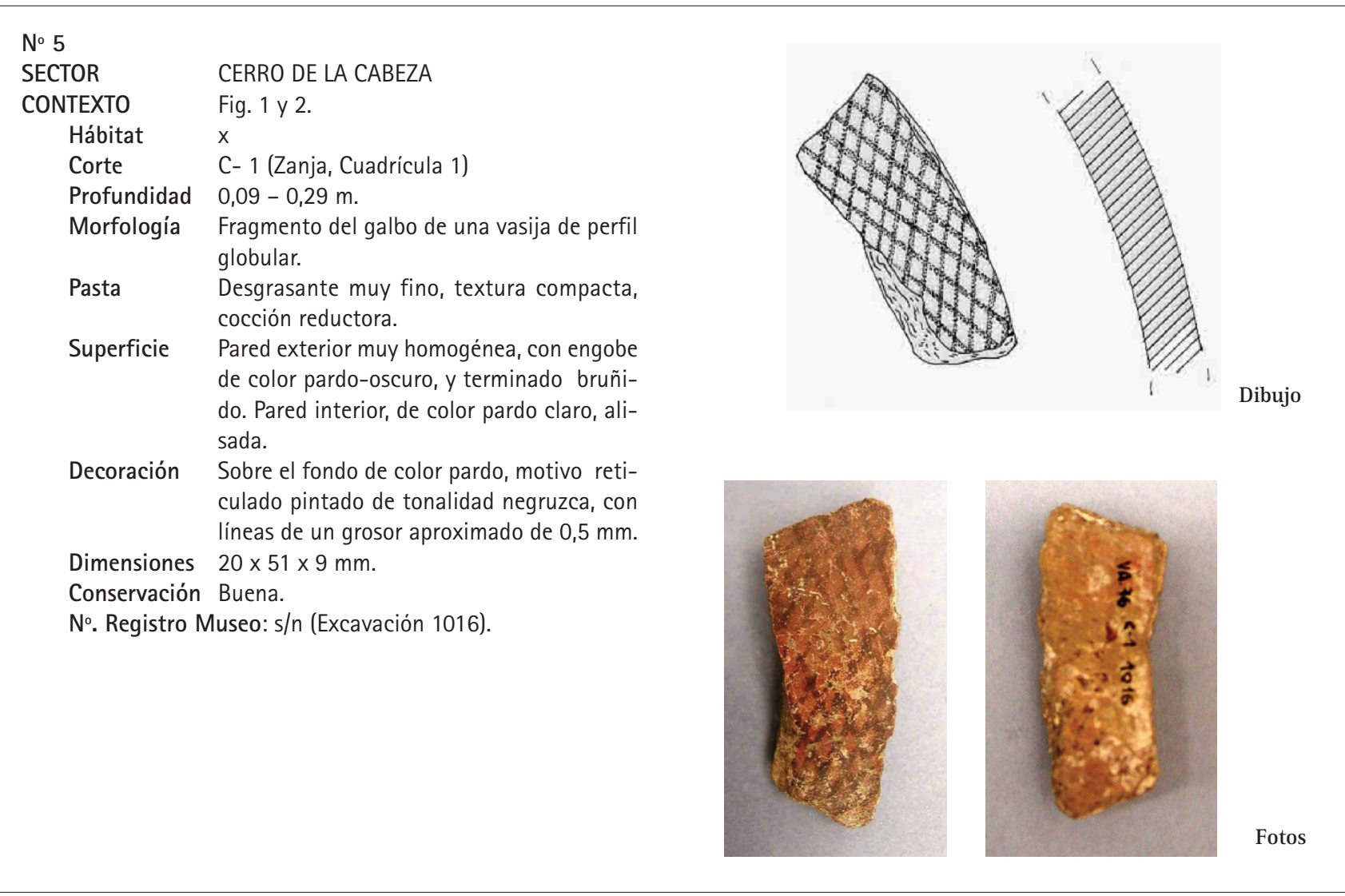




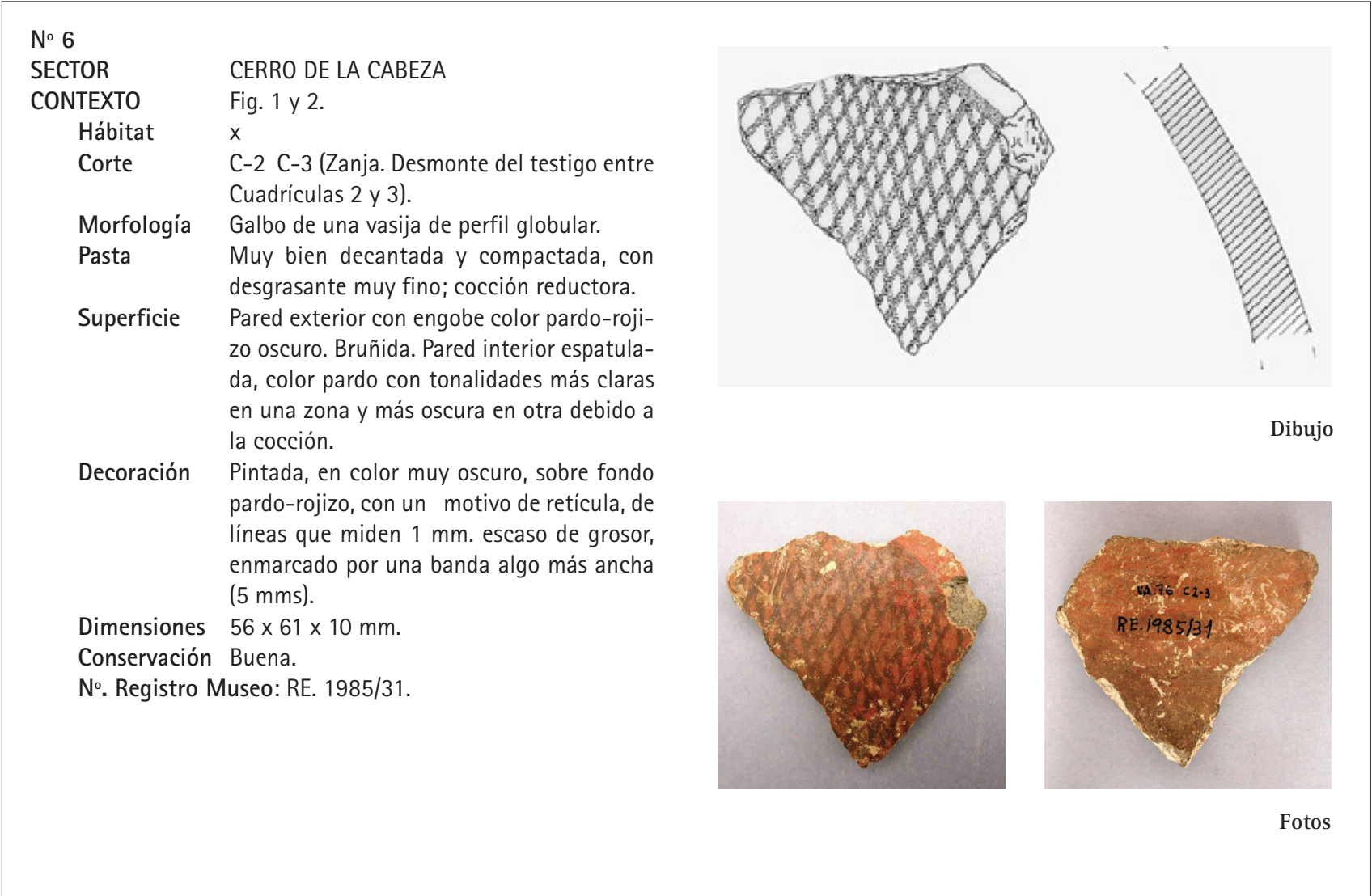

\section{№ 7 \\ SECTOR CERRO DE LA CABEZA \\ CONTEXTO Fig. 1 y 2. \\ Hábitat $\mathrm{x}$ \\ Corte $\quad$ C-2 C-3 (Zanja. Desmonte del testigo entre Cuadrículas 2 y 3 ). \\ Morfología Galbo de una vasija de perfil globular. \\ Pasta Muy bien decantada y compactada, con desgrasante muy fino; cocción reductora. \\ Superficie Pared exterior con engobe color rojo de ex- celente calidad. Bruñida. \\ Decoración Pintada, en color gris muy oscuro, pared in- terior espatulada, color pardo sobre el fon- do rojo del almagre, con un motivo de bandas paralelas diagonales, de $4 \mathrm{~mm}$. de grosor.}

Dimensiones $63 \times 40 \mathrm{~mm}$.

Conservación Muy buena.

No. Registro Museo: RE. 1985/13.
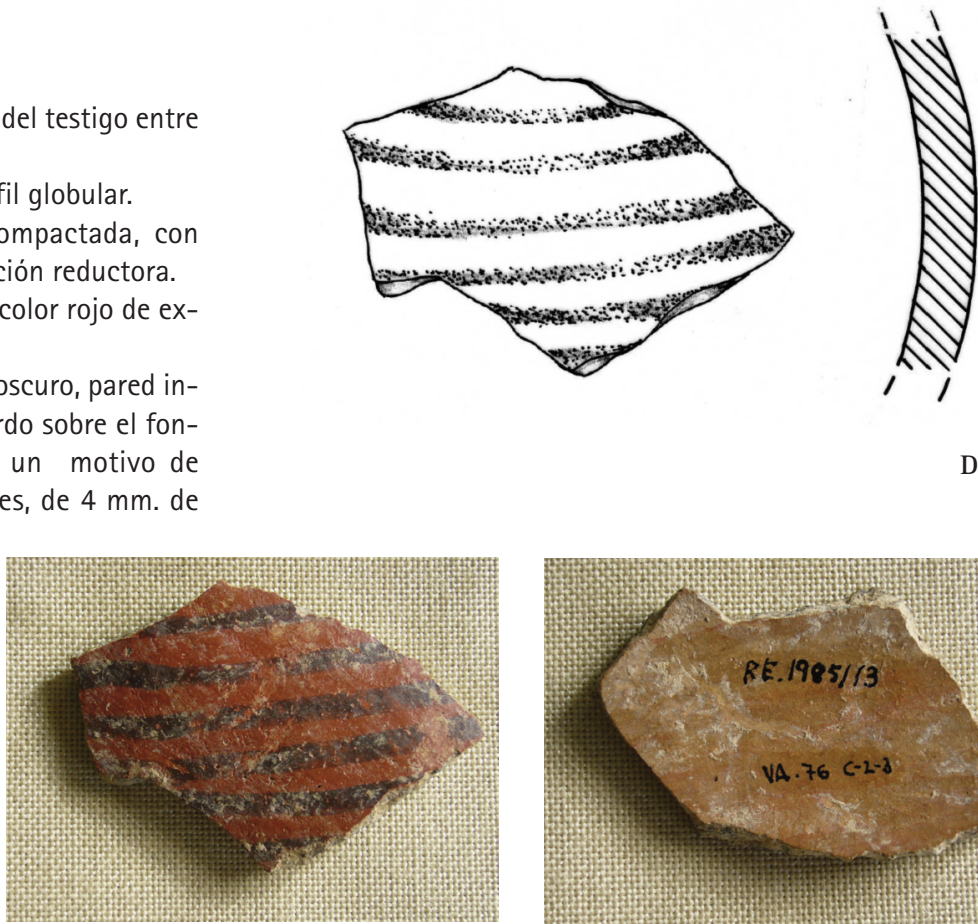

Dibujo

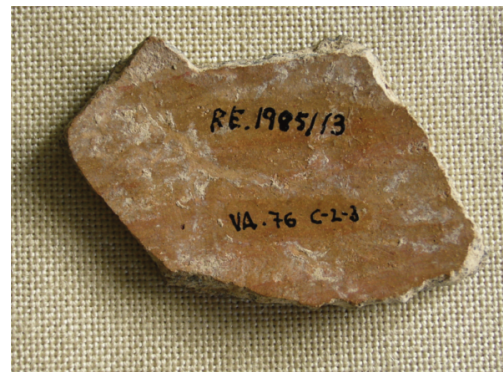

Fotos 

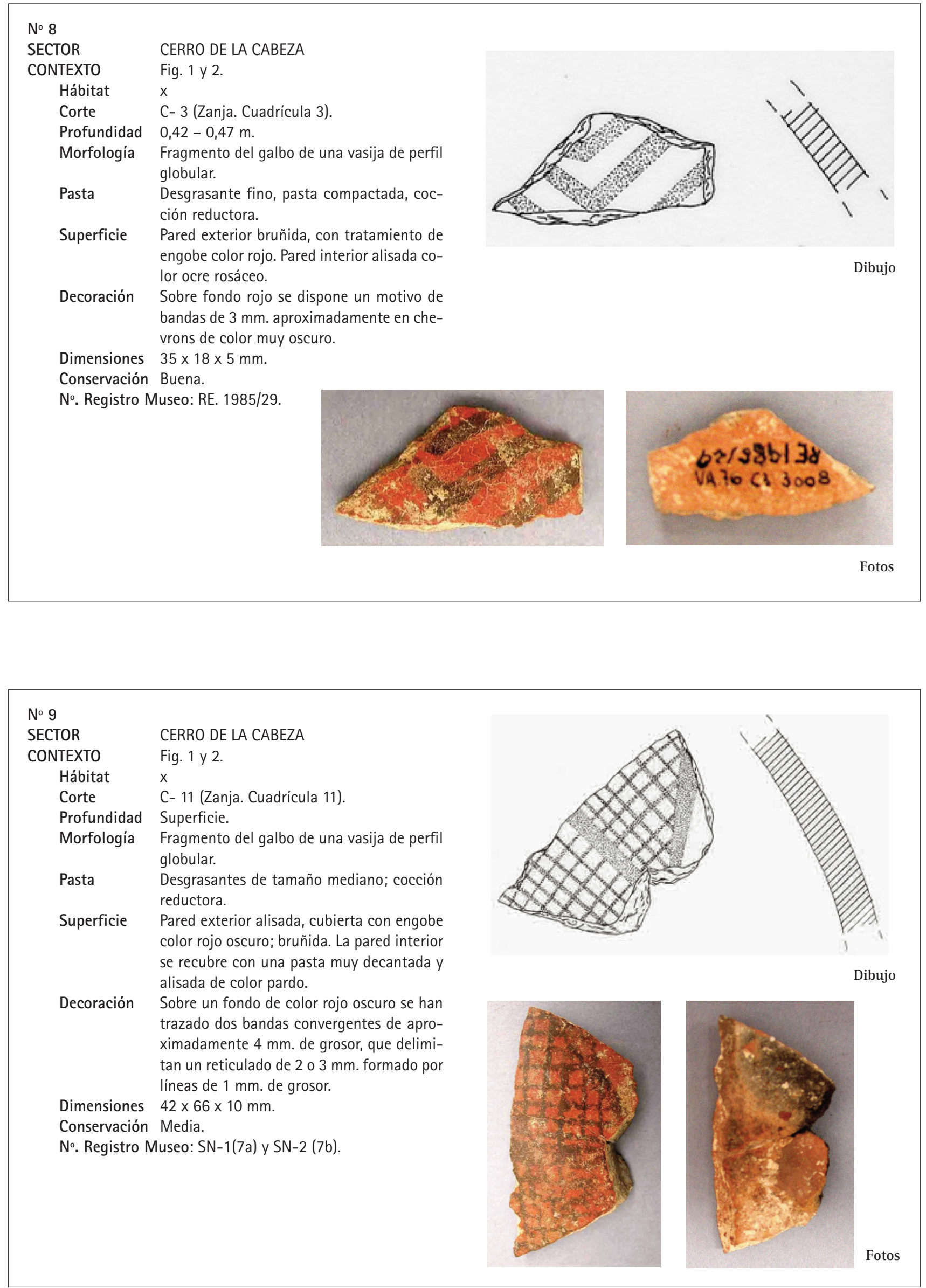


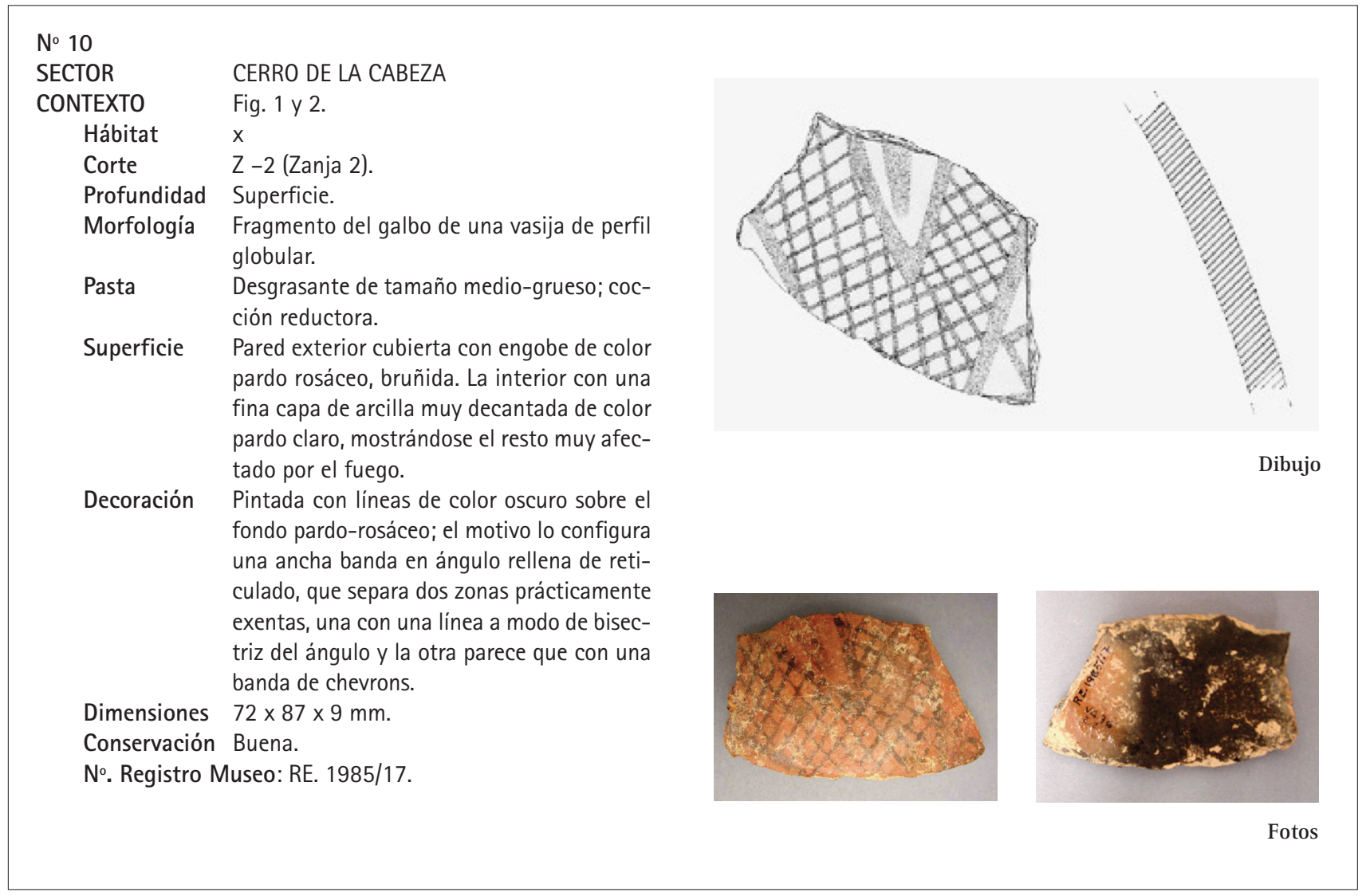

\footnotetext{
№ 11

SECTOR

CERRO DE LA CABEZA

CONTEXTO Fig. 1 y 2 (Murillo Díaz, Fernández Gómez y Oliva Alonso, 2005: 177).

$\begin{array}{ll}\text { Hábitat } & \text { X } \\ \text { Corte } & \text { F- } 70 \text { (Cabaña). }\end{array}$

Profundidad Superficie.

Morfología Fragmento del galbo de una vasija de.

Pasta Desgrasante de tamaño mediano; cocción mixta.

Superficie Pared exterior alisada, tratada con engobe de color rojo, bruñida. Pared interior espatulada, de color rojizo, excepto en un ángulo algo más grisáceo, debido a la cocción reductora.

Decoración Sobre un fondo rojo se pintan unas bandas de $4 \mathrm{~mm}$. que enmarca un reticulado romboidal, retícula de líneas de $0,3 \mathrm{~mm}$.
}

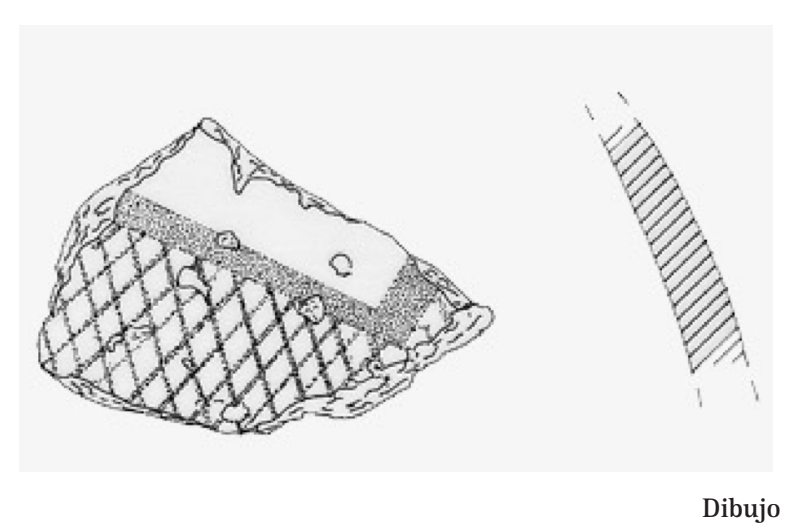

Fotos

Dimensiones $58 \times 40 \times 7 \mathrm{~mm}$.

Conservación Mala.

№. Registro Museo: RE.1985/14.
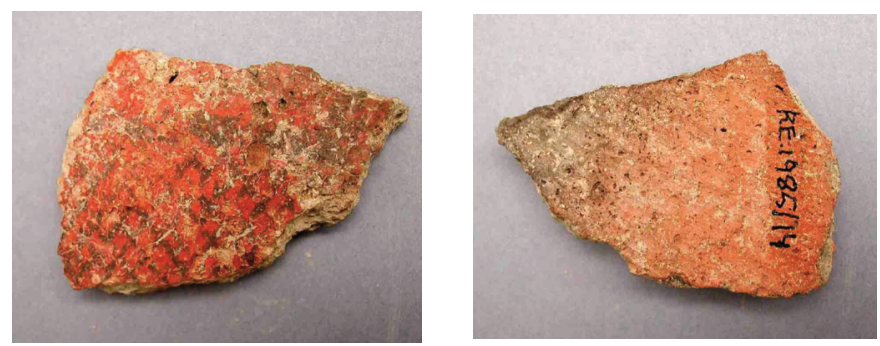

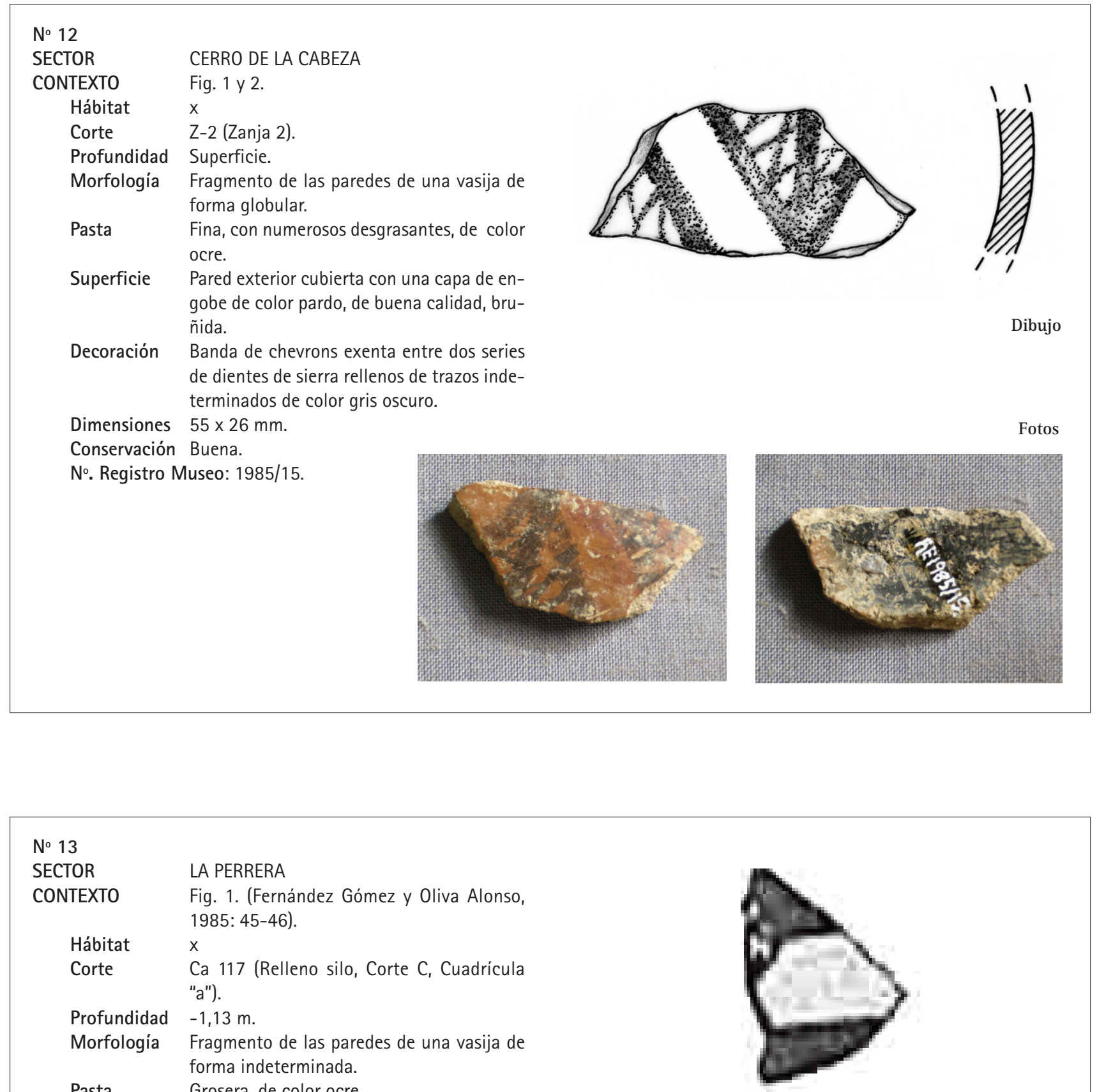

Superficie Alisada, con una gruesa capa de engobe color ocre rosado.

Decoración Dos bandas pintadas de color muy oscuro

Dibujo

№. Registro Museo: Sin número registro. 


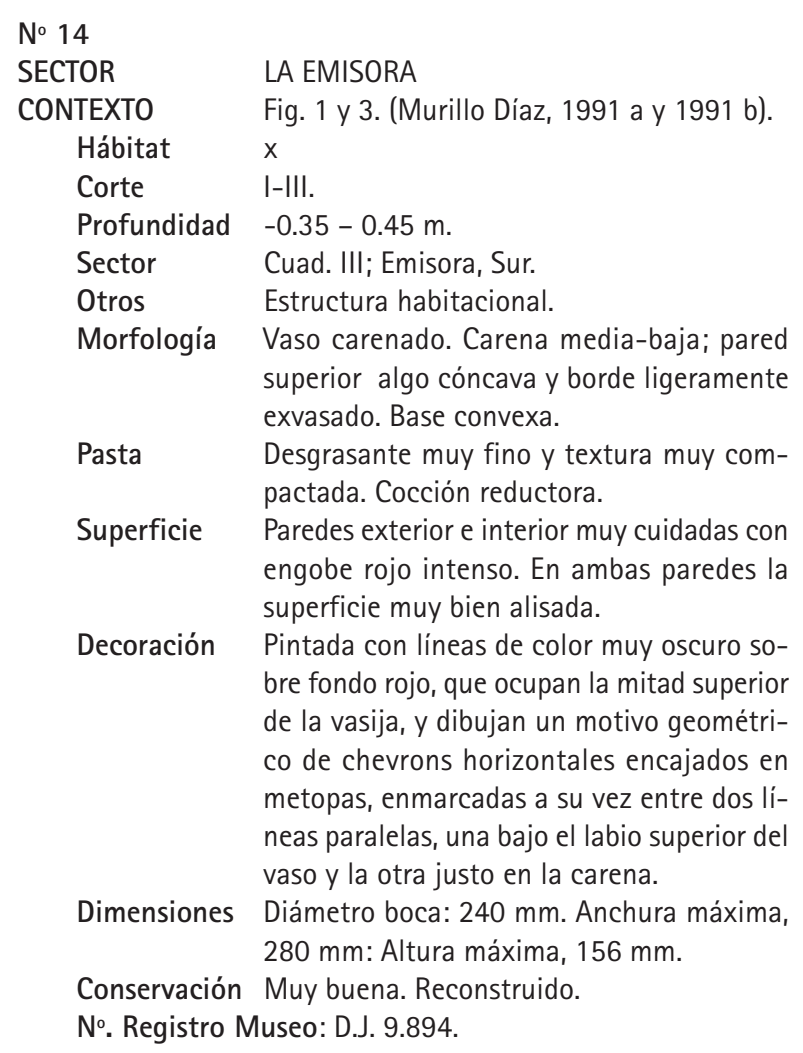

Superficie Paredes exterior e interior muy cuidadas con engobe rojo intenso. En ambas paredes la superficie muy bien alisada.

Decoración Pintada con líneas de color muy oscuro sobre fondo rojo, que ocupan la mitad superior de la vasija, y dibujan un motivo geométrico de chevrons horizontales encajados en metopas, enmarcadas a su vez entre dos líneas paralelas, una bajo el labio superior del vaso y la otra justo en la carena.

Dimensiones Diámetro boca: $240 \mathrm{~mm}$. Anchura máxima, $280 \mathrm{~mm}$ : Altura máxima, $156 \mathrm{~mm}$.

Conservación Muy buena. Reconstruido.

№. Registro Museo: D.J. 9.894.
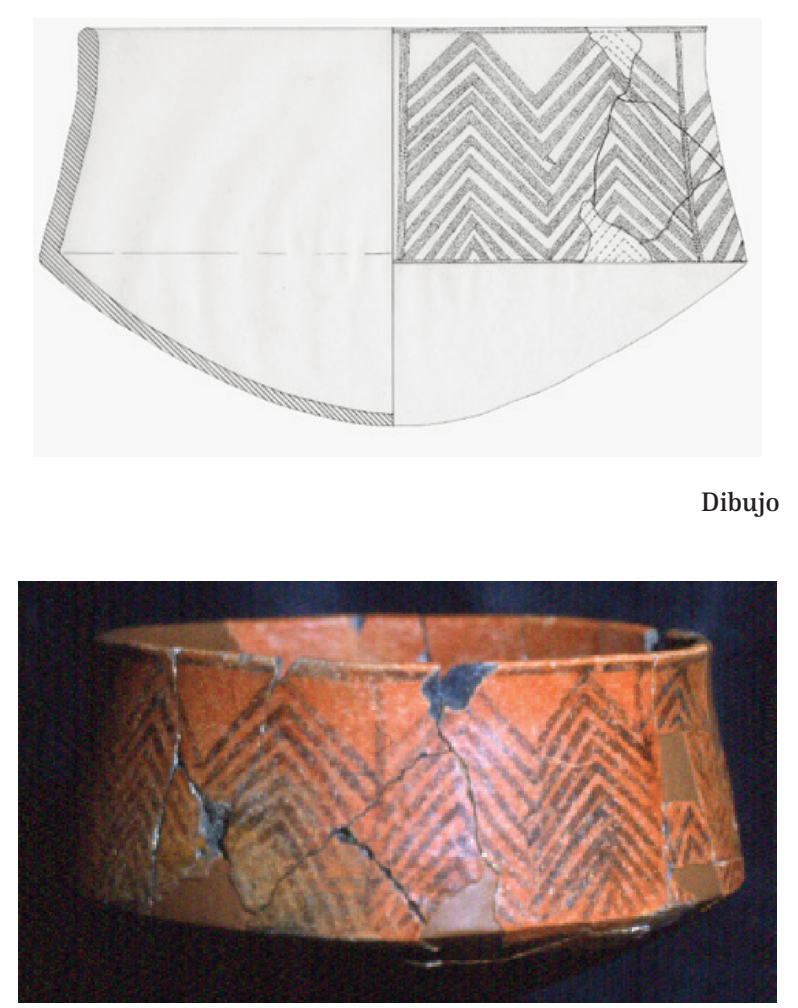

Foto

\section{CONCLUSIONES}

Este conjunto de cerámicas pintadas de Valencina poseen como elementos característicos una morfología de ollas y cazuelas, algunas carenadas, con unas técnicas de elaboración muy cuidadas: pastas con desgrasantes muy finos, finos y medios, cocción generalmente reductora o técnicas mixtas de horneado, superficies engobadas, con acabados bruñidos o espatulados, bien alisados en el interior y por el exterior de color rojo anaranjado, cuya decoración es siempre geométrica, con líneas que se cruzan formando reticulados cuadrados o romboidales, zigzags y chevrons, distribuyéndose en metopas, en tonalidades muy oscuras.

El resultado de esta riqueza cromática, con escasa representación peninsular, pone de manifiesto que las sociedades donde se desarrolla tienen un alto grado de complejidad social, en las que existe tanto una división técnica y territorial del trabajo como de la circulación de los productos, de control espacial y de desarrollo ideológico.

Estos artefactos cerámicos los consideramos como elementos ideotécnicos en estas sociedades de la Edad del Cobre, alejándose de lo meramente funcional, aunque gran parte de ellos se hallaran en este yacimiento en lugares habitacionales.

Las cerámicas pintadas de época calcolítica, aunque son escasas en la geografía peninsular, constituyen sin embar- go uno de sus elementos más significativos, desde el punto de vista arqueológico, por su gran calidad técnica y su especial cromatismo, que las hace inconfundibles. A ello tendríamos que añadir su posible sentido emblemático e ideológico, simbólico, que no podemos comprender, pero que se halla sin duda presente en el subconsciente de las gentes que decoraron de manera tan cuidada algunos de sus vasos de cerámica.

Su distribución geográfica (fig. 4) vemos que no es uniforme en la Península, sino fundamentalmente costera, con dos núcleos de concentración bien diferenciados: por un lado, el Sureste, la zona de Los Millares y Terrera Ventura (Gusi y Olaría, 1991: 169-176); por otro, el bajo valle del Guadalquivir en sentido amplio, con esta zona de Valencina que aquí estudiamos, como centro de mayor riqueza, con tres focos complementarios más pequeños, pero significativos, uno en Córdoba, con restos en la Cueva de los Mármoles (Asquerino, 1985: 239) y en el Llanete de los Moros (Montoro) (Martín de la Cruz y otros, 2000: 99), otro en Carmona, en la necrópolis de Campo Real (Berdichevsky, 1964: fig. 40; Bonsor, 1989: fig. 41-42; Conlin, 2003: 121 y 141), y un tercero, hacia el Sur, en la llamada Cueva de Los Algarbes (Tarifa, Cádiz), indicando un posible camino de entrada, o mejor aún, un hito más en el camino que trajo a estas cerámicas hasta el Bajo Guadalquivir y las hizo subir hasta Valencina. 


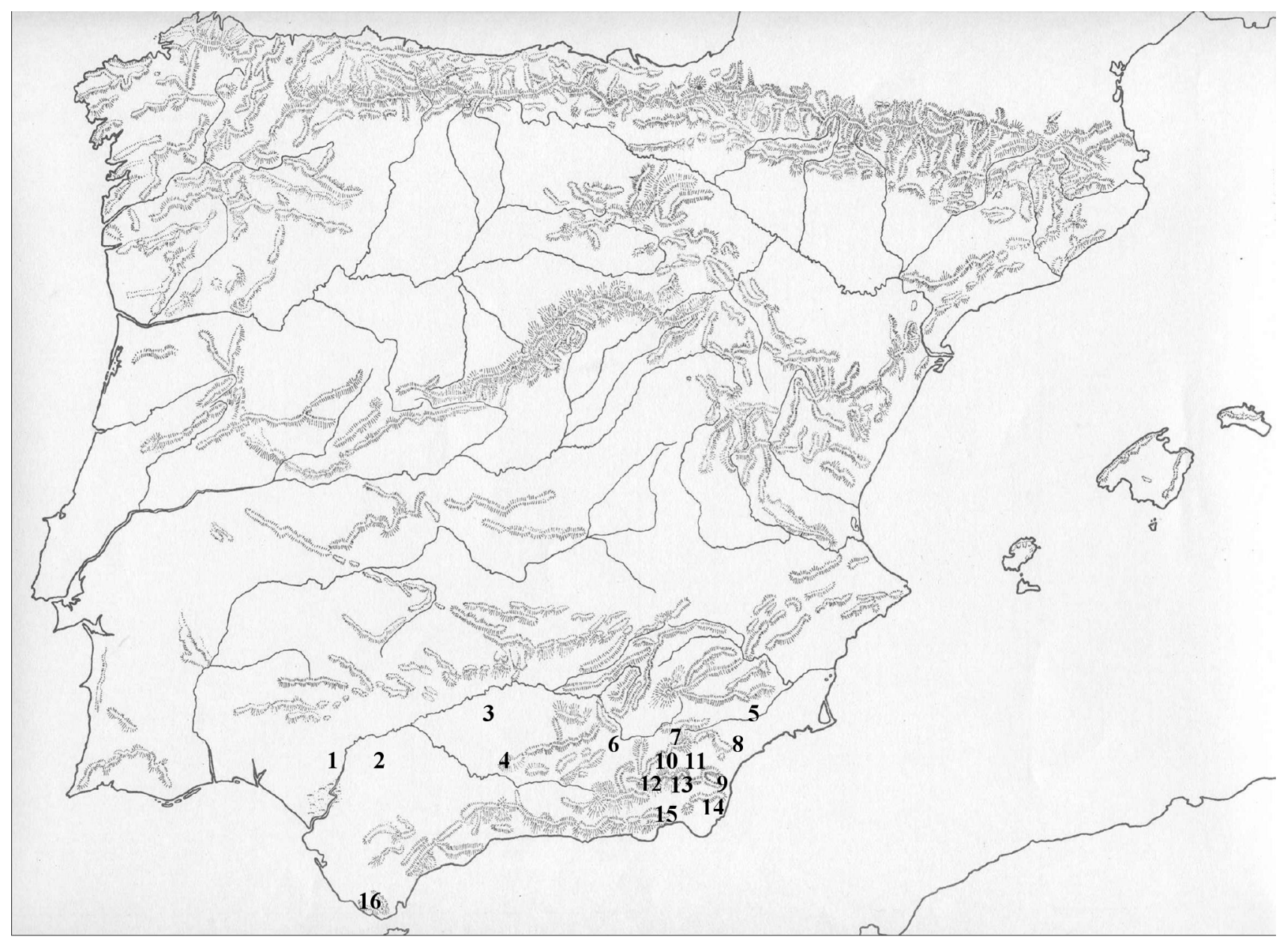

A FIigura 4. Distribución geográfica de las cerámicas pintadas.

1. Valencina de la Concepción (Sevilla)

2. Carmona (Sevilla)

3. Llanete de los Moros (Montoro, Córdoba)

4. Cuevas de los Mármoles (Priego, Córdoba)

5. Blanquizares de Lebor (Totana, Murcia)

6. Llano de la Cuesta de Amiel (Gorafe, Granada)

7. Llano del Jautón (Purchena, Almeria)

8. Poblado de Campos (Cuevas de Almanzora, Almería)

9. Loma de Belmonte (Mojácar, Almería)

10. Loma de la Eras (Tabernas, Almería)

11. Poblado de Terrera Ventura (Tabernas, Almería)

12. Los Millares (Santa Fe de Mondújar, Almería)

13. Loma de la Rambla de Huéchar (Gádor, Almería)

14. Las Peñicas (Nijar, Almería)

15. El Tarajal (Nijar, Almería)

16. Los Algarbes (Tarifa, Cádiz) 
En una visión de conjunto del territorio peninsular tendríamos que destacar, por tanto, como zona especialmente fértil el marco geográfico de Andalucia, lo que está de acuerdo por otra parte con su gran aportación en yacimientos arqueológicos del III Milenio y los constantes trabajos de investigación llevados a cabo en esta zona desde el siglo XIX hasta la actualidad, los cuales nos suministran una densa e interesante literatura científica sobre este período de la Prehistoria Reciente (Murillo Díaz, 2006).

Los contextos arqueológicos son en todos los yacimientos muy homogéneos, ya se trate de estructuras de habitación o de enterramiento, con una sola cosa a tener en cuenta: que mientras en los restantes yacimientos parecen darse estas cerámicas pintadas tanto en unas estructuras como en otras, y fundamentalmente en las últimas, como ajuar funerario, sobre todo en enterramientos de corredor, en Valencina de la Concepción no han aparecido hasta ahora nunca en ajuares funerarios, sino solamente en rellenos de zanjas, silos, pozos o cabañas, estructuras que debemos poner más bien en relación con ajuares habitacionales.

Sobre el origen de estas cerámicas tendríamos que decir, a pesar de lo mucho que desde entonces se ha escrito en contra (Arribas y Molina, 1979: 65; Martín Socas, 1983: 128; Gusi y Olaria, 1991: 169), lo mismo que hace años decíamos de los ídolos antropomorfos encontrados en uno de los pozos del mismo Valencina, y lo mismo que evidencian algunos ajuares funerarios: los contactos más o menos esporádicos 0 periódicos con pueblos del Mediterráneo Oriental, portadores de innovaciones tecno-económicas más avanzadas que las de los pueblos indígenas, que arribaban a nuestras costas en busca seguramente de materias primas, pero que a la vez nos dejaron, como harán otros pueblos de manera más intensa pasados los siglos, sus ideas espirituales y con ellas un repertorio simbólico, quizá muy simple, y en el que lamentamos no poder entrar, pero al que sí podemos asomarnos comparándolo etnográficamente con el de algunos pueblos primitivos actuales.

Resulta sugerente a estos efectos la hipótesis que José Luis Escacena presentaba hace unos años a propósito de los materiales que acababa de recoger en sus excavaciones de La Marismilla, un yacimiento que interpreta como un posible secadero de sal por medio del fuego, interpretación que ya hemos dicho en alguna ocasión nos costaba admitir en el Sur de Andalucía, aunque puedan presentarse posibles paralelos en el Centro y Norte de Europa, donde ciertamente no gozan de las características climáticas del Bajo Guadalquivir, ya que aquí es posible conseguir sal por simple desecación solar durante la mayor parte del año en cantidad considerable y con unos costes mínimos, al no ser necesarios ni el fuego ni las cerámicas.

Toda la enorme cantidad de fragmentos de cerámica recogidos allí los encuadra Escacena (1996: 245) en sólo unas cuantas formas de vasijas, el mayor número de las cuales co- rresponde a las cazuelas carenadas, que también tenemos en Valencina desde los estratos inferiores, antes de que aparecieran los característicos platos y fuentes de bordes almendrados y engrosados tan frecuentes y de tan larga perduración allí y en todos los yacimientos calcolíticos del Bajo Guadalquivir en sentido amplio. Por lo cual podemos situar la actividad de La Marismilla en esos momentos iniciales de Valencina, aunque luego este yacimiento se desarrolla y enriquece de tan sorprendente manera como todos conocemos, y La Marismilla desaparece.

La novedad que más nos interesa en relación con esas cerámicas de La Marismilla es la presencia en ellas de algunos fragmentos decorados, un porcentaje ínfimo, dice Escacena (1996: 247), y ya no con motivos pintados como los nuestros de Valencina, sino con motivos bruñidos, impresos o incisos, e incluso mediante añadidos plásticos, técnicamente por tanto distintos de los nuestros, pero formalmente muy parecidos en algunos casos, sobre todo aquellos que presentan diseños en forma de retícula o triángulos, exentos o rellenos, que después perdurarán durante largo tiempo. No parece emplearse nunca la pintura, pero sí buscarse el efecto estético del contraste de colores, cambiando el sistema de cocción, quizá poniendo simplemente las vasijas boca abajo en el horno, para producir bordes negros rematando vasijas de color ocre o rojizo, técnica que no conocemos en Valencina, donde, sin embargo, sí aparecen ya los motivos pintados, como hemos visto.

Y basado fundamentalmente en la presencia de estos bordes negros Escacena (1996: 254), retomando una antigua teoría de Martínez Santaolalla, seguida después ocasionalmente por otros investigadores, intenta buscar los orígenes de estas cerámicas en el mundo predinástico egipcio, poniéndolo en relación con grupos humanos foráneos que habrian irrumpido en la zona con un bagaje cultural desconocido casi por completo en el Neolítico peninsular e incluso en todo el Mediterráneo (1996: 253), encontrando las mayores concomitancias con la Cultura Badariense y restantes grupos humanos de pastores de bóvidos que inauguran el poblamiento estable del Alto Egipto, y en la que ya aparecen los diseños bruñidos en el interior de los recipientes, entre ellos el reticulado, como uno de los más frecuentes, a los que habría que añadir algunos materiales muy caracteristicos, sobre todo las puntas de flecha de base cóncava y las figurillas antropomorfas, aunque sean éstas muy distintas de las recogidas en Valencina, diferencia que Escacena piensa que se debe a que, una vez llegado a la Península, el concepto pudo evolucionar con independencia del foco oriental (1996: 258).

Más que de influencias directas del grupo Badariense se trataría de buscar, dice, un origen común, que se ha situado en el África sahariana, desde donde se habrían dirigido, por imperativo climático, unos hacia el alto Egipto y otros hacia el extremo occidental, para cruzar el Estrecho a finales del IV 
milenio a. C., como pastores de bóvidos portadores de una cultura todavía neolítica.

Y hasta aquí la tesis de Escacena que, por sugestiva que parezca, no nos parece apropiada para fijar el origen de las cerámicas de Valencina, el cual seguimos situando en el Mediterráneo Oriental, donde también vemos los diseños bruñidos, las cerámicas pintadas, los ídolos, y las gentes interesadas en la explotación del metal, las cuales no dejarán de venir a nuestras costas en los siglos siguientes.

Los motivos decorativos en sí son, como hemos visto, muy sencillos y reiterativos: siempre motivos geométricos, siempre las líneas quebradas, los chevrons, horizontales o verticales, y los reticulados, por lo general pintados todos con líneas de color oscuro sobre la superficie ocre o rojiza del vaso, color que se logra tanto por medios técnicos de cocción especial como artísticos, cubriendo la superficie del vaso de una capa de engobe que después se bruñe y espatula cuidadosamente, hasta lograr texturas de una gran calidad que nos hacen pensar que no se trata de vasos vulgares, sino de vasos significativos, especialmente diseñados y preparados para determinados servicios rituales, del mundo funerario en unos casos, para el ajuar de la casa en otros, quizá en relación con los diversos tipos de ídolos, placas, cilindros, falanges, antropomorfos, que se han encontrado en todos los yacimientos y de manera muy especial y variada en el mismo Valencina. Como imagen de lo que pudo ser el motivo decorativo completo de la mayor parte de nuestros fragmentos, podemos fijarnos en el ejemplar de la Cueva de los Algarbes, que actualmente se exhibe en el Museo Arqueológico de Sevilla.

La especial cocción a que nos referimos, la deducimos del color de las pastas, negras por lo general en su interior, evidenciando una cocción reductora, pero que aparecen al exterior de color claro, oxidadas. Se diría que las vasijas se dejaban secar al aire libre, y antes de que perdiesen por completo sus paredes la humedad, se bruñirian y espatularian, por medio de una piedra, un hueso o una caña debidamente preparados, con la cabeza redondeada. Una vez terminados de secar se introducirian en un horno a fuego reductor, sin corriente de aire. Cuando la cochura estuviera a punto de terminarse, e incluso cuando ésta ya estuviera terminada, se abriría la chimenea del horno para permitir durante algunos minutos la oxidación superficial de las paredes del vaso que, de esta manera, aparecería al exterior de aspecto rojizo $u$ ocre, facilitando su decoración por medio de líneas oscuras.

Sobre el significado de estos motivos lo que más nos llama la atención es la presencia casi constante del reticulado, y no solo en estos vasos pintados, sino también en los más frecuentes platos y fuentes que presentan retícula bruñida en su fondo, y de los cuales hemos hallado numerosos fragmentos mezclados con aquellos en el núcleo habitacional y algunos ejemplares completos formando parte de los ajuares funerarios, sobre todo en el tholos del Cerro de la Cabeza (Fernández y Ruiz Mata, 1978). Hemos querido buscar algu- na interpretación a este hecho, pero no la hemos hallado. Podría quizá considerarse como representación simbólica de una red que sería imagen del cosmos, en el sentido que lo hace Mircea Eliade (1955: 121), concibiendo al propio cosmos como un tejido, en el que todo, lo mismo que en la vida humana, se halla ligado por una textura invisible, y en el que ciertas divinidades son las conductoras de esos hilos que, en última instancia, constituyen una vasta ligazón cósmica.

A las líneas quebradas en forma de chevrons se las ha considerado en ocasiones como imagen del agua, y de esa manera se representan ciertamente las aguas de los ríos sobre los que se deslizan las barcas solares en la pintura egipcia. Champeaux y Stercks (1985: 66) las consideran imagen del mar.

Pensamos también en la posibilidad de que todos estos temas decorativos no hagan en la cerámica más que reproducir los diseños que los indígenas utilizarían en sus objetos de materia orgánica, sobre todo cestería y tejidos (Alfaro Giner, 1984: 114 ss. y 154 ss.), utilizando similar policromía y manteniendo hasta los mismos significados simbólicos, aunque éstos irian disolviéndose progresivamente. Podriamos poner en relación el fin de los motivos decorativos de estas cerámicas calcolíticas, tanto los bruñidos como los pintados, con la pérdida de influencia de esos significados simbólicos. Cuando no pasan a ser más que meros motivos decorativos de carácter exclusivamente estético, desaparecen, pues lo que les hacía mantenerse era el mensaje de que eran portadores. Ello explicaría también, además de su sencillez, que sean los motivos que aparecen decorando, no solo algunas de sus cerámicas más representativas, sino también las láminas de oro de la Cueva de Los Algarbes (Posac, 1975, fig. 12), similares a los que presentan los todavía más sencillos fragmentos de láminas de oro del mismo Valencina (Fernández Gómez, 1997: 30).

Son todo conjeturas en las que hemos pensado con frecuencia, aunque nada podemos saber con certeza. En cualquier caso lo que más nos cuesta admitir, a la vista de toda esta serie de motivos decorativos, es pensar que no tengan ningún significado especial, que no sean más que un simple diseño artístico sin más trascendencia que hacer del vaso algo bonito. Creemos que, de alguna manera, tienen que ser reflejo de una idea presente al menos en el subconsciente de quien ejecutó el motivo, y que era una misma la idea que buIlía en la mente del artesano que decoró con retícula o chevrons los vasos, pintados o espatulados, de Valencina, el de la tumba de Carmona y el de la Cueva de Los Algarbes. Como tampoco puede carecer de significado el motivo inciso que decora el fondo de un plato de esta misma cueva de Los Algarbes, y en el que de nuevo aparece el reticulado, este ortogonal y delimitado por una línea periférica que encierra un espacio rectangular (Posac, 1975: lám. XI, 2).

Son, evidentemente, unas mismas ideas, una misma manifestación del subconsciente, algo que, al verlo, resultaba elocuente para aquellos indigenas de la Edad del Cobre, y que consideraban adecuado ya para presentarlo a la divini- 
dad, ya como ofrenda a los espíritus de la casa, o como ajuar del difunto en su viaje al más allá. Y a todas ellas tendríamos que integrarlas dentro del grupo de las cerámicas simbólicas, que tienen en el vaso de Los Millares (Martín y Camalich, 1982, fig. 1, n²3, p. 271) decorado con ojos, uno de sus ejemplares más significativos. Y poner el origen de estas ideas en el Mediterráneo Oriental, aunque aquí, en la Península, se le diera una interpretación propia, como parece deducirse del hecho, por ejemplo, de que estos simbólicos ojos estén presentes no solo en alguna cerámica, sino también en una gran cantidad de ídolos de nuestros yacimientos, y no los encontremos nunca, por el contrario, en los vasos ni en los ídolos de aquella procedencia (Doumas, 2000).
La cronología de estas cerámicas tenemos que fijarla en un Calcolítico Pleno, tanto por su posición en el nivel superior del relleno de las estructuras siliformes de "La Emisora", relleno constituido en su totalidad por materiales de esta época, como por los contextos de los fragmentos recogidos en las diversas estructuras del Cerro de la Cabeza, zanjas, silos y pozos, colmatados en su totalidad por este mismo tipo de materiales, para situar los cuales tenemos las fechas de C-14 que nos proporcionaron los ídolos localizados en el que llamábamos pozo número uno, que se elevaban al 3.910 y al $4.050 \mathrm{BP}$, es decir, hacia el 2.100 a.C. ambas (Fernández y Oliva, 1980: 43), en un momento precampaniforme, cultura de la que no hemos hallado ni en un lugar ni en otro ningún testimonio.

\section{BIBLIOGRAFIA}

Alfaro Giner, C., (1984): Tejido y cestería en la Península lbérica. Historia de su técnica e industrias desde la Prehistoria hasta la Romanización, Biblioteca Praehistorica Hispana, XXI, Madrid, 1984, Ministerio de Educación y Ciencia.

Arribas, A. y Molina, F., (1979): El poblado de "Los Castillejos" en las Peñas de los Gitanos (Montefrío, Granada). Campaña de excavaciones de 1971. El corte num. 1. Granada, Universidad.

Asquerino Fernández-Ridruejo, Ma. D., (1985), Cerámicas pintadas de la Cueva de los Mármoles. XVII Congreso Nacional de Arqueología. Zaragoza, pp. 239-245.

BERDICHEVSKY SCHER, B., (1964): Los enterramientos en cuevas artificiales del Bronce I hispánico. Biblioteca Praehistorica Hispana, VI. Madrid, Consejo Superior de Investigaciones Científicas. Instituto Español de Prehistoria.

BoNSOR, G. E., (1899): Les colonies agricoles prerromaines de la Vallé du Betis. Revue Archeologique.

ChampeauX, G. de y SterckX, S., (2000): Introducción a los símbolos. Madrid. Encuentro Ediciones.

Conlin, E., (2003): Los inicios del III milenio a. C. en Carmona: Las evidencias arqueológicas. Carmona. Revista de Estudios Locales, 1, pp. 83-143.

DoumAs, Christos G., (2000): Early cycladic culture. The N.P. Goulandris Collection, Atenas.

ElIADE, M., (1955): Imágenes y símbolos. Madrid. Ed. Taurus.

Escacena Carrasco, J. L., Rodríguez de Zuloaga Montesino, M. y Ladrón de GuEvARA SÁNCHEZ, I., (1996): Guadalquivir salobre. Elaboración prehistórica de sal marina en las antiguas bocas del río. Sevilla. Confederación Hidrográfica del Guadalquivir.

FernÁndez GómeZ, F., (1997): Tesoros de la Antigüedad en el Valle del Guadalquivir. Sevilla. Consejeria de Cultura-Cajasur.

FernÁndez Gómez, F. y Oliva Alonso, D., (1980): Los ídolos calcolíticos del Cerro de la Cabeza, Valencina de la concepción (Sevilla). Madrider Mitteilungen, 21, pp.20-44.

Fernández Gómez, F. Oliva Alonso, D., (1985): Excavaciones en el yacimiento calcolítico de Valencina de la Concepción (Sevilla). El Corte C (La Perrera). Noticiario Arqueológico Hispánico, 25, pp. 7-132.

Fernández Gómez, F. y Oliva Alonso, D., (1986): Valencina de la Concepción (Sevilla). Excavaciones de urgencia. Revista de Arqueología, 58, febrero, pp. 19-33.

Fernández Gómez, F. y Ruiz Mata, (1978): El "tholos" del Cerro de la Cabeza en Valencina de la Concepción (Sevilla). Trabajos de Prehistoria, 35: 193-224.

GusI I Jener, F. y OlaRIA I Puyoles, C., (1991): El Poblado Neoeneolítico de Terrera Ventura (Tabernas, Almería). Excavaciones Arqueológicas en España, 160. Ministerio de Cultura.

HAIN, F. H., (1982): Kupferzeitliche Tierknochenfunde aus Valencina de la
Concepción. Sevilla. Studien über Tierknochenfunde von der lberischen Halbinsel, 8. München.

JORDÁ CERDÁ, F., (1989): Posible origen de algunos motivos y temas artístico-religiosos del calcolítico peninsular. Empúries, 48-50, pp. 392-395.

Martin de la Cruz, J. C., Sanz Ruiz, M. P. y Bermúdez Sánchez, J., (2000): La Edad del Cobre en el Llanete de los Moros (Montoro). El origen de los pueblos en la campiña cordobesa. Revista de Prehistoria, 1. Área de Prehistoria de la Universidad de Córdoba.

MARTín SoCAS, D. Y OTROS, (1983): La cerámica con decoración pintada del Eneolítico en Andalucía Oriental. Tabona, IV, pp. 94-130.

Martín Socas, D. y CAMAlich MASSIEU, Ma. D., (1982): La "cerámica simbólica"y su problemática (aproximación a través de los materiales de la Colección L. Siret). Cuadernos de Prehistoria de la Universidad de Granada, 7, pp. 267-306.

Martinez Fernández, Ma. J., (1999): La cerámica prehistórica. Algunos aspectos de fabricación. Antiquitas, 10, pp. 31-35.

Martinez FernÁndez, Ma. J., (1999): La cerámica prehistórica. Algunos aspectos de fabricación. Antiquitas, 10, pp. 31-35.

Murillo DíAz, T. (1987): Excavación en el yacimiento calcolítico de El Polideportivo de Valencina de la Concepción (Sevilla), 1985. Anuario Arqueológico de Andalucía. Urgencias. Sevilla. Consejería de Cultura.

Murillo DíAz, T., (1991a): Excavaciones de urgencia en el poblado calcolítico de Valencina de la Concepción (Sevilla), 1988-1989. Anuario Arqueológico de Andalucía. Urgencias. Sevilla. Consejería de Cultura.

Murillo Díaz, T., (1991b): Excavaciones de urgencia en el poblado calcolítico de Valencina de la Concepción (Sevilla), 1988-1989. Revista de Humanidades, 2. Centro Asociado de la U.N.E.D., Sevilla.

Murillo Díaz, T., (2006): Historia e Historiografía de un yacimiento de la Edad del Cobre: Valencina de la Concepción, Sevilla. Monografía 8. Centro Asociado de la U.N.E.D. Sevilla.

Murillo Díaz, T., Fernández Gómez, F. y Oliva Alonso, D., (2005-6): Una cabaña de la Edad del Cobre en Valencina de la Concepción (Sevilla). Revista de Humanidades, 14. Centro Asociado de la U.N.E.D., Sevilla.

Murillo, T., Cruz-Auñón, R. y HuRTAdo, V., (1990): Excavaciones de urgencia en el poblado calcolítico de Valencina de la Concepción (Sevilla). Anuario Arqueológico de Andalucía. Urgencias. 1985. Consejería de Cultura.

ORTON, C., TYeRS, P. Y VINCE, A., (1997): La cerámica en Arqueología. Crítica. Barcelona.

POSAC Mon, C., (1975): Los Algarbes (Tarifa). Una necrópolis de la Edad del Bronce. Noticiario Arqueológico Hispánico. Prehistoria, 4. Madrid, pp. 85-119.

Ruiz MATA, D., (1983): El yacimiento de la Edad del Bronce de Valencina de la Concepción (Sevilla) en el marco cultural del Bajo Guadalquivir. Actas del / Congreso de Historia de Andalucía. Diciembre de 1976 pp. 183-208. Monte de Piedad y Caja de Ahorros de Córdoba. 